\title{
Profiles and Causes of Urban Poverty in Small Islands: A Case in Ambon City, Maluku Islands Indonesia
}

\author{
Wardis Girsang ${ }^{1}$, Marthin Nanere ${ }^{2}$ \\ ${ }^{1}$ Department of Agribusiness, Faculty of Agriculture, University of Pattimura, Ambon, Maluku, Indonesia \\ ${ }^{2}$ La Trobe Business School, College of Arts Social Sciences and Commerce (ASSC), La Trobe University, Melbourne, Australia
}

\section{Email address:}

girsangwardis@yahoo.com (W. Girsang),m.nanere@latrobe.edu.au (M. Nanere)

\section{To cite this article:}

Wardis Girsang, Marthin Nanere. Profiles and Causes of Urban Poverty in Small Islands: A Case in Ambon City, Maluku Islands Indonesia. International Journal of Economic Behavior and Organization. Vol. 4, No. 3, 2016, pp. 18-27. doi: 10.11648/j.ijebo.20160403.11

Received: January 28, 2016; Accepted: October 28, 2016; Published: November 19, 2016

\begin{abstract}
Poverty rate is still found to be around two times higher in rural areas. However, excesive urbanization, has increased the number of slums in urban areas. Thus, informal economic sectors and poverty will probably become more urbanized in the future. The main purpose of this article is to study the profiles, causes and livelihood strategies of urban poor households in small islands city. Mixed methods of survey, field observation and focus group discussions including in-depth interview by using questionnaire instruments were used to obtain data from 200 selected households. Findings suggest that the profiles of urban poor households have been identified in terms of social demographic, household economic expenditure and urban poverty rate and living standard indicators. Then, the significant causes of urban poverty have been examined as internal and external factors. Internal factors are cultural and structural-including the number of family members, women-headed household and poverty status. External factors are geographical poverty traps, including distance to city center, sanitation status and misused of government policy on rice for the poor program. Livelihood strategies of urban poor households are occupational multiplicity to reduce risks and uncertainty.
\end{abstract}

Keywords: Urban Poverty, Profile, Livelihood Strategies, Ambon Islands

\section{Introduction}

The current development issue in Indonesia is poverty. Center Board of Satistic(CBS) or Badan Pusat Statistik [1] stated that national poverty rate decreased gradually from $18.2 \%$ in 2002 into $11.25 \%$ in 2014 . However, poverty line is probably too low and sensitive to change so that there is around $40 \%$ of people who live in the 'near poverty line'that are vulnerable to become poor when there is an unexpected income shock. It was also estimated that $18 \%$ (20 million) of the poor live in urban areas [2], however, the dynamic of poverty shows that declining number of people from poor to non-poor is followed also by the increasing number of people from not poor to poor household at the same year [3]. In addition, economic growth was followed by social economic inequality from 0.35 to 0.41 in the last two decades, particularly between eastern and western part of Indonesia. Papua, West Papua, Nusa Tenggara Timur and Maluku are provinces in eastern Indonesia that have the highest poverty rate due to the geographical, cultural and structural poverty traps including limited access of transportation infrastructure and inadequate government public services in rural areas.

Beside inequality between regions, poverty is shifting from rural to urban regions. Indeed, poverty rate in Indonesia in 2014 was higher in rural than that of urban areas, that is $14.7 \%$ and $8.3 \%$ respectively. The same pattern occurs at the province level. In Maluku province archipelago, rural and urban poverty rate was of $33.9 \%$ and $10.2 \%$ respectively. In general, however, poverty rate in rural and urban has decreased gradually but the depth of poverty tends to increase in rural areas. This means that living standard of poor household in rural areas became further from the poverty line. Thus, urbanization to Ambon city is inevitably, and population growth increased up to $4 \%$ per year [1].

Preferably, urbanization should be followed by poverty reduction in urban area because of better infrastructures, job opportunities and per capita income improvement. Guan and McElroy [4] find out that immigrant in small islands is 
determined by literacy, level of per capita income, lower unemployment, working-age population and political status. Therefore, urbanization is expected to reduce poverty in urban and rural area because rural people will receive remittance from urban immigrants who come and live in urban area [5]. In fact, rural poverty reduction is followed by increasing number of urban poor due to the expansion of city area, natural population growth and urbanization [6].
Eventhough the rate of poverty decreased very slowly in the last decade, however, the quantity of poor people in urban areas in Indonesia increased gradually from 10,390,000 in 2013 to 10,510,000 people in 2014 [1]. The same pattern occurred in the province of Maluku as the number of urban poor increased from 47,860 to 49,830 people in the same year between 2013 and 2014 (Table 1).

Table 1. The number and percentage of poor people in urban and rural Indonesia and Maluku, 2012-2014.

\begin{tabular}{|c|c|c|c|c|c|c|}
\hline \multirow{2}{*}{ Region } & \multicolumn{3}{|c|}{ Number of poor (in thousands) } & \multicolumn{3}{|c|}{ Number of poor $(\%)$} \\
\hline & 2012 & 2013 & 2014 & 2012 & 2013 & 2014 \\
\hline \multicolumn{7}{|l|}{ Indonesia $^{1}$} \\
\hline Rural & 18970 & 17780 & 17770 & 15.72 & 14.28 & 14.17 \\
\hline Urban & 11050 & 10390 & 10510 & 9.23 & 8.42 & 8.34 \\
\hline Rural and Urban & 30020 & 28170 & 28280 & 12.49 & 11.36 & 11.25 \\
\hline \multicolumn{7}{|l|}{ Maluku $^{2}$} \\
\hline Rural & 288.88 & 268.12 & 266.28 & 28.87 & 26.34 & 26.28 \\
\hline Urban & 57.89 & 47.86 & 49.83 & 9.78 & 7.93 & 7.8 \\
\hline Rural and Urban & 346.77 & 315.98 & 316.11 & 21.78 & 19.49 & 19.13 \\
\hline
\end{tabular}

${ }^{1}$ Berita Resmi Statistik No.52/07/Th.XVII, 1 Juli 2014:2 (BPS, 2014: www.bps.go.id)

${ }^{2}$ Berita Resmi Statistik No 07/01/81/Th.XVI, 1 Juli 2014:2 (BPS Provinsi Maluku, 2014: maluku.bps.go.id)

The problem is that urban population has increased considerably but poverty in urban area tends to increase gradually [7]. At the same time an excessive urbanization created the slum areas, informal sectors and inequality between urban and rural region [7], [8], [9]. In Indonesia, more than $60 \%$ of laborers worked in informal sector because industries are unable to absorb excessive, unskilled and low educated workers from agriculture sector [8]. Therefore, more than half of the poor will reside in urban areas and without government intervention, the rate of urban poverty will be higher than that of rural poverty in 2020 [10]. Further, unemployment and disguised unemployment has also increased as well as the number of people who work in informal sector. This indicates that informal sectors are considered vulnerable, low productivity, lack of asset protection, weak bargaining position, difficult access to market and sensitive prices to inflation [11]. This article examines the profile, causes and livelihood strategies of urban poverty in the small Ambon city island.

\section{Methodology}

Ambon city is a densely populated area and the capital city of both the government of Ambon city and the province of Maluku, eastern Indonesia. During the colonialization era, Ambon city island was used by the Dutch company, i.e. Verenigde Oostindische Compagnie (VOC), as the business center of spices collection in the whole Maluku and north Maluku regions including Ambon-Lease, Seram, Buru, Banda island. Then, the Dutch imperialism took over and occupied Ambon islands as the center of center for business, political and government administration to control the whole resources and people of Maluku islands for more than 400 years. Post colonization, Ambon city still became the center for business, politic, social and cultural and also the only gate to entry and exit from Maluku to the outer regions. Thus Ambon city economy is driven by market, trade, services, and industry sectors. Ambon city has the highest economic growth and Human Development Index as well as the highest income per capita if it is compared with the other 10 districts in the province of Maluku.

As the center of economic and business activities, annual population growth in Ambon city island is up to 4\% and the number of population has increased up to 395,423 people in 2014 or $25 \%$ of total provincial population. This population growth has created the problem of excessive urbanization and numbers of the following unavoidable problems such as new slum areas, clean water shortage, crowded city transportation, poor garbage management, unpredictable flood in the rain season, limited land for housing and land use conflict, including watershed environmental degradation and urban poverty.

To investigate urban poverty, a number of 200 respondents of household were selected from 10 villages/kelurahan of total 5 sub-districts in Ambon city (Figure 1). These research locations in Ambon city were chosen based on geographical areas, regional plan and the distance to the city center. The main reason is that the difference of poverty rate between locations relate to the distance to the city center and villages. The furthest village from the city center due to the transportation and communication access to public services and market is probably the poorest village in the region. 


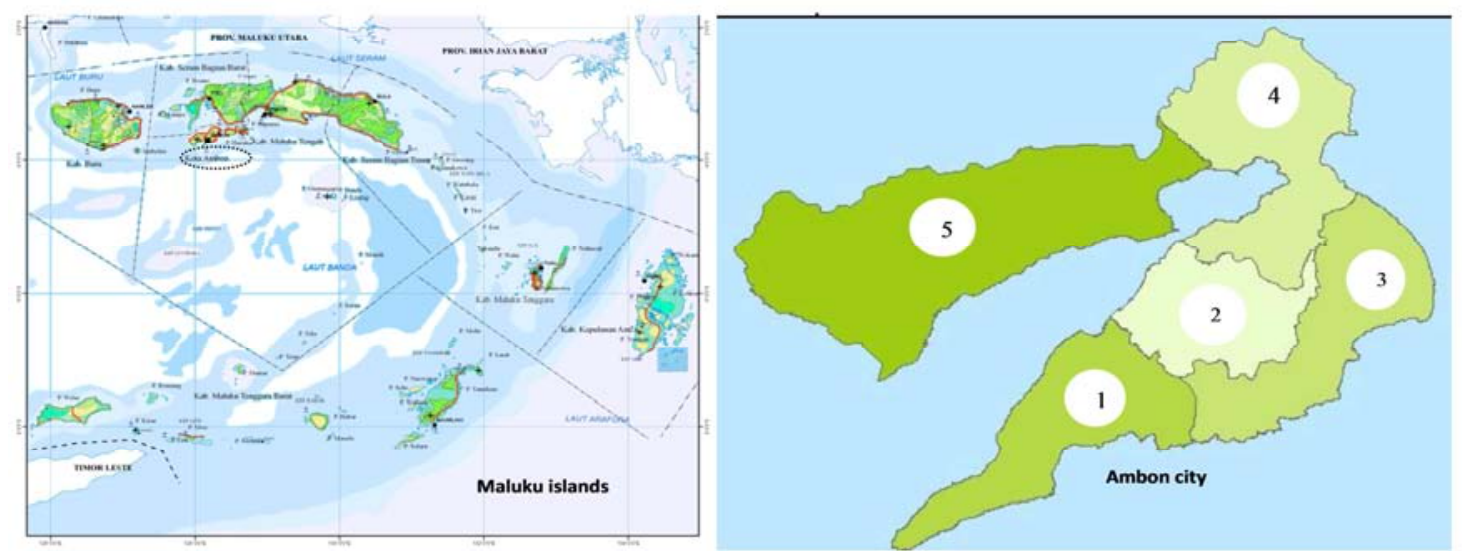

Figure 1. Map of Maluku province and Ambon city.

Notes: Ambon city is divided into 5 sub-districts: 1. Nusaniwe (tourism); 2. Sirimau (City center: provincial and city government, trade and retail, economy and finance, ports and resettlements); 3. Leitimur Selatan (agriculture); 4.Teluk Ambon (Passo: industry, new resettlement, trade and services, regional transit terminal, handy craft center); 5. Teluk Ambon Baguala (Poka=RumahTiga: Education and research, resettlement, ferry transportation)

The total number of respondents were 200 head of households selected randomly from 10 villages in 5 subdistricts in Ambon city island. Data were collected by welltrained enumerators, including students and lecturers who have field survey experience in Maluku regions. Mixed methods were used in terms of in-depth interview and field observation using questionnaire instruments. Data analysis was developed through cross tabulation and multiple regressions. In additioan, focus group discussions with local government, village leaders and research team members, and seminars with experts were conducted to validate the research data and findings.

\section{Results and Discussions}

\subsection{The Historical Background of Ambon Island}

Ambon island is a small island with size around $743 \mathrm{~km}^{2}$ with hilly topography land that is grown by multiple mix cropping of forest, agriculture and integrated with coastal zone areas, which is called dusun systems. Dusun is beyond traditional agroforestry because dusun is human made as indigenous technology that mixed and integrated forest trees, agriculture and coastal-fisheries areas. The basic principle is to protect sea through protecting island land: From forest to agriculture [sago palm, clove and nutmeg] and fisheries [mangrove, and coral reef].

In the past, Maluku island was known as spices islands and attracted many countries to come for business of spices and the country imperialsm [12]. China imported clove from spice islnds in $200 \mathrm{BC}$, and then Portugal controlled spices trade in 1500. Later, however, Holland started to monopolize and took over spice islands business from Portugal in 1600, and then fully controlled spice trade in 1650. In 1750, Holland destroyed spices product in order to increase and control the price, and took over spice trade from England that occupied spice island briefly in the 1800 s. Since then, the Dutch government not only controlled spice business but also imperialized and colonialized Maluku islands.

Different from the Dutch government who trusted Christian, Japan government more trusted to Moslem communities during Japanese colonization in 1942. This created social segregation by religion and ethnic that was developed by the Dutch in Ambon island. Ambon city was the basis of administration to imperialize and occupy the other islands in Maluku.

Post Indonesian independence in 1945, the army of KNIL (Koninklijk Nederlands-Indisch Leger) or local army who served the king of Nederlands was dismissed in 1950. Then there were around 5000 of KNIL army went to Holland and lived there as the resident of the Dutch government. It was noted that the Dutch government did not provide education access to the whole people whilst at the same time developed 'devide et impera' strategy. This means spreading provocation and conflict to control the communities.

As the capital of Maluku province, nowdays Ambon city in Ambon island, is the most important island amongst of 1340 islands in Maluku province. The total area of Maluku is $712,479 \mathrm{~km}^{2}$ and $92.4 \%$ of its region is surrounded by sea and $7.6 \%$ is covered by land. As part of Ambon island, the area of Ambon city is around $359 \mathrm{~km}^{2}$ or $48 \%$ of total area of Ambon islands [1]. In fact, Ambon city is the main entry-exit gate to Maluku province, center of government administration, transportation, education, tourism, industry, economic, trade, service and business as well as social, cultural and political activities. Besides, population growth of Ambon city increased considerably around 4\% per year and the number of population increased up to 400,000 people in 2014. Therefore, Ambon city has become urbanized because of excessive migration from periphery island areas. Ambon city is the icon of multicultural and a world peace city identity of Maluku islands. Ethnicities in Ambon city include 
Ambon-Lease, Seram, Buru, Kei islands and Southeast Maluku, Banjar, Buton, Bugis, Chinese, Moslem and Christian regligion.

Based on its spatial distribution of island communities characteristics [13], Ambon city can be categorized as small island archipelago rather than solitary island. Different from the other archipelagic small islands, which is known as remote, less-developed, including agriculture economic and periphery with insularity communities, Ambon island was known as the city island during the history of spices trade since the colonization era in 1500 s. As a result, the challenge of Ambon city island today is population density that increased significantly from 940 people $/ \mathrm{km}^{2}$ in 2012 into 1049 people $/ \mathrm{km}^{2}$ in 2014 [1]. This is around 8 times higher than that of provincial population density. Besides, population density was unequal between villages/kelurahan within the city, i.e. between 167 people in Soya village and up to 28,346 people per $\mathrm{km}^{2}$ in kelurahan Rijali (Rijali village). Higher population density in the village/ kelurahan will increase chronic urban poor households in the city.

\subsection{Profiles of the Urban Poor Households}

\subsubsection{Social Economic}

Based on field observation, most of the poor households (87\%) were at productive age between 20 and 59 years old. This means that they were categorized as economically active poor target groups. However, education level of $21 \%$ of these poor households was elementary school, of $74 \%$ were junior and senior high school and the rest 5\% was graduated from higher education/ university.

Most of poor households have to work as unskilled labor in informal small scale farm, industry, trade and services. This implies that literacy level is necessary but not sufficient to improve household income without increasing capability to get a better job and to create new business. Moreover, $81 \%$ of urban poor have no access to financial institutions whilst the rest of $19 \%$ have access to financial institution with high interest rate. Paradoxically, financial capital was used by poor families for consumptive rather than productive economic activities.

Next, there were only $15 \%$ poor households who have certain jobs with low wage labour whether as civil servants or private employees. The rest of $85 \%$ households have income uncertainty as they work in informal economy sector without skilled labor such as farmer-fishers, motorcycle drivers, services and labor as well as micro-enterprises, home industry and trade [14]. In this situation, most of urban poor households have to adapt with uncertainty and complexity of daily life to fulfill basic needs of family members.

Data also showed that $46 \%$ of urban poor household has more than 5 family members or up to $85 \%$ have children between 2 and 8 people. Thus, they need higher income to pay for food and the other non-food basic needs. This was a crucial challenge for the urban poor people, particularly for $18 \%$ of women-headed household who have double role in the households.

Social economic of urban poor households can be understood from the structure and profile of household expenditures. Because poor household is assumed to lack saving and productive assets, therefore expenditure can be assumed as the household income. Research showed that average urban poor household expenditure in Ambon city was around IDR 10,77 million/household per year or IDR 29,722/household/day. This value was equivalent with US $\$ 3.1 /$ household/day (US\$1=IDR9,500). It means IDR7430 or US\$0.78 per capita per day.This was about two folds lower than that of World Bank poverty standard (US\$2/capita/day).

The type of urban poverty in Ambon city can be called as absolute-chronic urban poverty because around $67 \%$ or almost $2 / 3$ of expenditure was allocated to fulfill food basic needs. Data showed that the highest food expenditure was rice, then followed by fish, cigarette, vegetable and sugar. Rice and fish contributed up to $37 \%$ of total household expenditures (Figure 2).

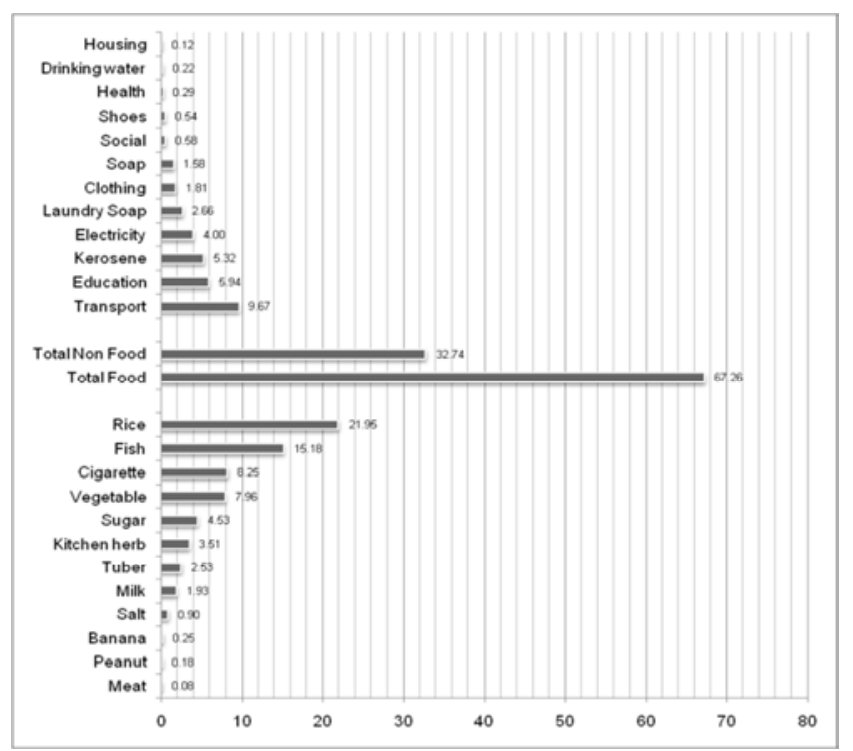

Figure 2. Ambon City: Food and no food expenditures of poor households (Rp10,667,005/Year; $n=200)$.

In general, poor households were usually live together with family members so that they would use US $\$ 3.1 /$ household/day collectively not $\$ 0.78$ per capita per day individually. The price of commoditiesis is influenced significantly by available of sea transportation in Maluku islands [1], therefore when shipment transportation is not available during the heavy wave season, the price of imported commodities will increase considerably, and the purchasing power of the urban poor will be weakened, particularly for rice, vegetables, sugar and cigarettes. Eventhough fish is produced locally, however, the price will increase during the heavy wave seasons. In addition, household expenditure for cigarettes was almost 4 times higher than that of expenditure for milk. Then, health issue was the last priority of poor families in line with limited clean water and sanitation infrastructures, nutritious food and access to public health service. 


\subsubsection{Poverty Rate}

Poverty is multidimensional and is defined differently according to the different perspectives involving income, education, health, cultural, democratization, opportunity and capacity to have access to a better life [15], [14]. On one side, poverty is defined according to economic. On the other side poverty is also defined based on non-economic indicators, including general ethical and morality values. National Central Board of Statistic (CBS) used economic indicators in term of household expenditures. However, Women Civil Society Empowerment and Family Planning Agency used both economic and non-economic indicators including religious and cultural values. Both institutions used education, income and health as the main indicators of poverty.

Based on CBS indicators, provincial poverty rate has decreased significantly at the same time from $31.1 \%$ in 2007 to $23 \%$ in 2011 and then be likely to decrease very slowly in the last 3 years. Different from CBS data, Family Planning Agency data showed that poverty in Ambon city was around $14.5 \%$ in 2012. This poverty rate was three folds higher than that of CBS poverty rate. According to $\mathrm{CBS}$ and Family Planning institutions, the number of urban poor people in Ambon city was between 17,399 and around 55,359 people, respectively. The difference of urban poverty rate between CBS and Family Planning is probably due to the different indicators, method, sample size and time line to collect the data.

Low poverty rate was probably caused by using too low standard for chronic or absolute poverty line [16], particularly in Ambon city island. The minimum average expenditure at Ambon city is estimated around two folds higher than the national standard poverty line [14]. National CBS used expenditure per capita per month, that is around Rp11,496 per capita per day or US \$1.19 in 2012 in Ambon city. Then, according to Sajogyo's indicators, poverty line in Ambon city was estimated round Rp13,333 (USD\$1.34) /capita/ day [17], [18]. This poverty line was almost half lower than World Bank and United Nations Development program.

Based on rice equivalent value of Sajogyo's indicators [17], almost $60 \%$ of households were poor whereas $40 \%$ was not poor. The high percentage of poverty is supported by the previous data, suggesting that $67 \%$ of household expenditure is allocated to fulfill basic food needs. How poor are the urban poor households? The poor level of $60 \%$ of urban poor households can be depicted into four groups according to Sajogyo's categories (1978) as follow: (1) 22\% of the "poor" household having expenditure less than US\$1.4/capita/day; (2) $18 \%$ of the "poorest" households having expenditure less than US $\$ 1.05 /$ cap/day; and (3) the rest $20 \%$ of the "destitute" households having expenditure less than US \$ 0.79/cap/day (1US\$=IDR9500 in 2012). In general, average household expenditure is around IDR7.430 or US\$0.78 per capita/day. This was as the same as the household expenditure of the poor household in 2009 , i.e. IDR7,152 or US\$0.75/capita/ day [14], [19]. This indicates that the expenditure or income of urban poor households have a tendency to stagnant because the higher household income is negated by increasing inflation rate of basic needs in the last 5 years in Ambon city (Figure 3).

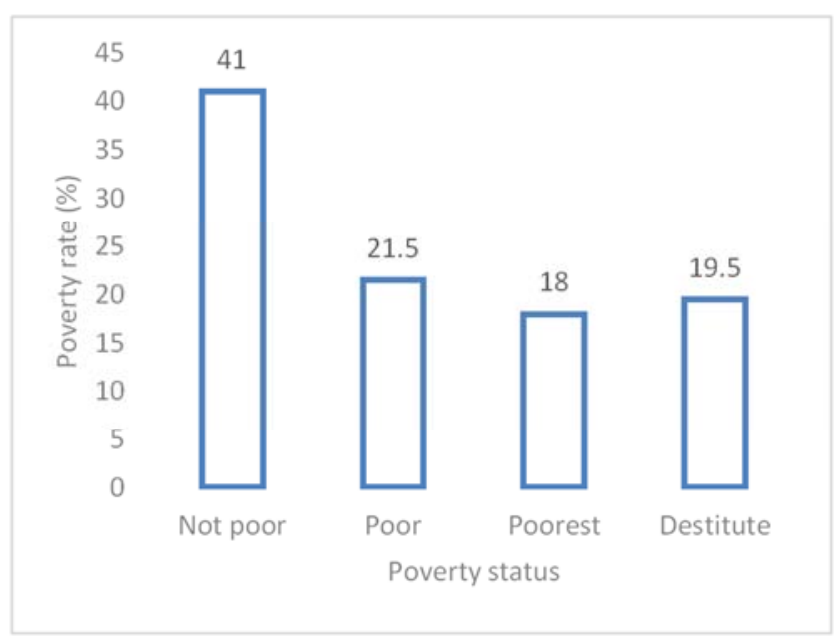

Figure 3. Urban poverty rate in Ambon city.

To include non-economic components of urban poverty, it can be used multidimensional indicators in terms of health, education and living standards. Research showed that around $81 \%$ of household was deprived on sanitation, $73.5 \%$ deprived on asset's ownership, 55.5\% deprived on housing and of $47.5 \%$ deprived on access to clean drinking water [20], [21]. There were also $26 \%$ of households that used wood as fuel cooking and the other $6.5 \%$ had no access to electricity. This shows the depth of poverty and the priority target group of urban poverty alleviation. It should be started from sanitation improvement particularly access to clean water and then is continued to improve assets development and opening access to deserved housing, affordable drinking water and electricity (Figure 4).

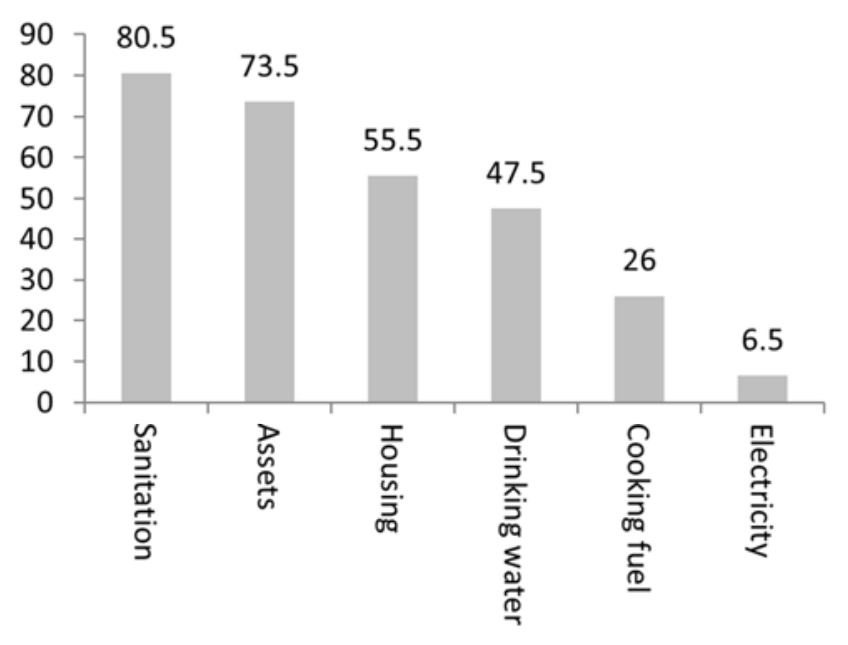

Figure 4. Deprived household living standards rate in Ambon city.

According to urban poor households, poverty is poor attitude and behavior. This means that poverty is defined as laziness, lack of effort, low motivation, feebleness, belief on superstition, and very low need of achievement to improve 
and to have a better business and living standard. Poor households are perceived as lack of access to health, sanitation and education services. Government may provide health insurance and free school fee for elementary school but lack of skill has made people difficult to get a decent job.

\subsection{Causes of Urban Poverty}

\subsubsection{Internal: Cultural and Structural Factors}

The internal factors of urban poverty are more emphasized on individual, cultural and structural weakness. Results show that almost half of urban poor household (49\%) perceive that low individual income or head of household is the main cause of urban poverty. Unlike urban area, poverty in rural area is embedded in the social structure and customary law that allows people to redistribute local natural resource assets and to exchange labor and food. Therefore, poverty in rural area is not due to the inability to fulfill food because they have food from the farm, but it is due to lack of cash money. Urban poverty is lack of both food and cash money because urban poor households will find it difficult to sustain and survive without cash money and food.

Basically, around $21 \%$ of urban households do not know the cause of poverty. This means that they do not know that they are poor. The other $4 \%$ of household stated that the cause of poverty is low skill and education level. Low level of knowledge, education and skill will make it difficult to get appropriate job and income. Therefore, most of urban poor households work in informal economic activities without personal skill. The next internal factor causing urban poor household is the deprivation on human capital assets. The other cause of urban poverty is lack of access to health service $(15 \%)$ and poor attitude and behavior (13\%). Low access to health service indicates the inability to develop network to the outside social groups, private and public institutions. In addition, poor attitude and behavior of urban poor household can be seen in term of narrow mind-set minded, having no plan about the future, laziness, consumptive behavior, individualistic and lack of participation to social organization and local development program.

The other poor behavior is that they tend to expect free aids from government but are unable to make productive work. Based on cultural perspective, local poor people behavior is a life style and attitude to keep living in happiness in sptite of the poor situation, including reluctant to admit the poor status but accept all kinds of government free assistances for the poor. This situation was worsened by inadequate social capital assets. In fact, most urban poor households have low trust, lack of network and participation at local organization and development. This situation will deprive social and financial capital assets because social, financial and political capital assets have significant influence on urban poverty [22].

Based on the number of family members, urban poor households did not realize that limited income could become restriction to provide better nutrition, education, knowledge and skill for the children. Children were perceived as family asset but at the same time they also became a burden to the household economy. This implies that urban poor family would produce the next urban poor household generation because the current family is unable to provide enough healthy food and convenience housing. As a result, research findings suggest that the number of family members have had a positive influence on urban poverty (Table 2).

Table 2. Ambon City: Coefficients of Determinant Factors Influencing Urban poverty ( $n=200)$.

\begin{tabular}{|c|c|c|c|c|c|c|}
\hline \multirow{2}{*}{ Model } & & \multicolumn{2}{|c|}{ Unstandardized Coefficients } & \multicolumn{3}{|c|}{ Standardized Coefficients } \\
\hline & & B & Std. Error & Beta & t & Sig. \\
\hline \multirow{7}{*}{ Variables } & (Constant) & 12.652 & 1.826 & & 6.930 & $.000 * *$ \\
\hline & Poverty Rate and Status & -2.462 & .285 & -.598 & -8.627 & $.000 * *$ \\
\hline & Number of Family Members & 1.063 & .172 & .423 & 6.161 & $.000 * *$ \\
\hline & $\begin{array}{l}\text { Types of Village and Distance to } \\
\left.\text { City Center }{ }^{c}\right)\end{array}$ & -1.053 & .227 & -.280 & -4.645 & $.000 * *$ \\
\hline & Volume of Rice Subsidy & -1.320 & .317 & -.237 & -4.159 & $.000^{* *}$ \\
\hline & Sanitation Status & 1.103 & .407 & .150 & 2.710 & $.007 * *$ \\
\hline & Women Head of Household & .722 & .362 & .104 & 1.994 & $.048^{*}$ \\
\hline
\end{tabular}

$\mathrm{R}=0.706$ and $\mathrm{R}$ Square $=49.9 \%$ with Std. Error of the Estimate $=3.467$

$* *=$ Significant at $\alpha=0.01$ and $*=$ significant at $\alpha=0.05$

Types of region (Village in Urban Area/Ambon City); 1= Agriculture and Tourism Regions Base: Hutumuri, Soya danLatuhalat (Farthest regions to the City Center); $2=$ Trade and terminal (transit) region: Passo; $3=$ Education and housing and horticulture region: RumahTiga, Waiheru; 4= City Center region and government Office: Batu Merah_1, Batu Merah_2, Benteng and Waihaong (Nearest Regions to the City Center).

In spite of the number of family members, it is also found that male-headed household, would improve urban poverty whilst female-headed household would increase urban poverty. Because of divorced or widow status, female-headed household has a double role to raise children and to work for fulfilling basic needs of family members. The absence of parents, particularly female-headed household will influence the education of the children [23]. Moreover, inadequate urban poor household's income would force the children to work to earn cash money for additional household income. As a result, children education tends to suffer. Field observation showed that of 30 respondents of child workers in Ambon city [24] about $37 \%$ of them were dropped out from school because they had to help the mother to get additional income, whilst the rest $40 \%$ and $23 \%$ were studying at elementary and junior high school, respectively. 


\subsubsection{External: Geographical and Poverty Policy Traps}

The previous Table 2 shows that there are 6 important determinants of urban poverty in Ambon city islands. These factors include level of poverty, types of village and distance to city center, rice subsidy policy, the number of family members, sanitation and female-headed household status. Amongst all these variables, three of them, i.e. poverty level status, type of village and distance to the city, and rice subsidy are external factors that have negatively influenced on urban poverty whereas the other three variables, i.e. number of family members, sanitation and women-headed of household status are internal or structural and cultural factors that have influenced positively on urban poverty.

These external factors of urban poverty can be interpreted in several points. Firstly, urban poverty status can be categorized into poor, near poor and not poor. Data show that a better effort to improve poverty status will reduce the number of households who live in urban poverty line. To improve poverty level from poor to not poor status will be determined by the capacity of local government to improve the status of urban poor households. There is strong indication of the number of households who are in and out poverty status every year. This indicates that urban poor household status is dynamic [3] and should be evaluated annually to see the improvement of the target groups.

Secondly, the distance of the village to city center has negatively influenced on urban poverty. In fact, poverty was higher in the center of Ambon city than in the periphery areas of the city. In general, most people who live in the periphery were local people whereas most poor households who live in the slum areas in the city center are migrants family coming from outside, i.e. Java and Sulawesi islands.

As there is limited land and lack of economic attractors in the periphery areas whilst population growth has increased considerably due to high unskilled family migrants from inner and outer islands like Java and Sulawesi islands [25], it can be argued that excessive urbanization will continue, and poverty in Ambon city islands will become more urbanized. Due to the lack of access to the market, government services and transportation, urban poverty in small Ambon city islands can be seen as a spatial and geographical poverty trap [26], social isolation and residence segregation trap [27].

Thirdly, the quantity of rice subsidy has influenced negatively on urban poverty. Low price of rice subsidy is the main government policy to reduce cronical urban poverty. Based on historical background, rice for the poor was started in 2001. As a crucial commodity in Indonesia, rice is the national staple food. Rice price influences inflation and poverty because of following reasons: (a) if rice price increases by $10 \%$ then the number of poor will increase by $1.3 \%$; (b) around $73 \%$ of expenditure of the poor household is allocated to pay for food and up to $30 \%$ is allocated for rice [28]; (c) about 70\% of Indonesian farmers are rice netconsumers; and (d) rice is political commodity, and supplydemand side and the stability of rice price are controlled by the government by arranging the national stock, and determining ceiling and floor price of rice.
However, national rice for the poor policy has also created dependency on rice consumption, and at the same time increased the volume of imported rice to substitute local staple food consumption. Research findings show that almost half of total respondent has received rice subsidy between 10 $\mathrm{kg}$ and $60 \mathrm{~kg}$, whilst the other half has never received rice subsidy. According to government rules, each poor household should received rice around $15 \mathrm{~kg}$ per month. In fact, based on occupation, the highest percentage of households receving rice subsidy includes those working in services (labors and drivers), followed by farmer, civil servant and private business employees.

Most farmers receive between $10-30 \mathrm{~kg}$ whereas most labors and drivers receive between $31-60 \mathrm{~kg}$, followed by civil servant and home industry workers. Based on field observation, $52 \%$ of 'not poor households' receives rice for the poor program, whereas poor households do not receive rice subsidy, that is $40 \%$ of the poor, then $60 \%$ of the poorest and also $72 \%$ of destitute households. This indicates that rice for the poor program fails to address the main target groups.

There are several possible reasons of misused rice for the poor program. Firstly, fund channeling and rice distribution mechanism is susceptible to misuse, particularly at subdistrict and village level [2]. Secondly, poor people do not have enough cash money to buy rice subsidy collectively and the price of rice subsidy was probably higher than that of standard due to the additional cost for transportation within and between the islands.

Thirdly, most of the poor household in urban area come from another region (province or district) and do not have local identity card, therefore basically they did not have right to receive the program. Fourthly, it is also possible that private traders would buy rice subsidy at subsidy price because they have cash money to buy at large quantity and then they will sell it at higher price to the local market. This could provide explanation why the total volume of rice subsidy allocated for poor people reduced from $15 \mathrm{~kg}$ into 10 or $5 \mathrm{~kg}$ / household per month. This could be the reasons why part of poor household never receive rice for the poor program.

Finally, better sanitation may reduce urban poverty because healthy environment could prevent diseases, illnesses and costs for medicine as well as create healthy and productive labour. The main problem of urban poor households is that $72 \%$ of them are migrant family living in the highly urbanized place in Ambon city with limited access to sanitation and clean water [24]. This has created at least 14 types of diseases and the first 5 top diseases include: (1) headache, fever, cough and influenza (41\%); (2) Malaria (13\%); (3) Diarrhea and heartburn (9\%); (4) arthritic pain (8\%) and uric acid (5\%). These diseases are demographic shock to the economy of poor urban households and need to be integrated with infrastructures development including clean water, housing and sanitation [27].

\subsection{Livelihood Coping Strategies}

Coping strategies are choices of poor household to get 
occupation, and then to manage income and expenditure in order to sustain livelihood. Due to the high risk and uncertainty of income and vulnerability because of weather shock, illness of family members, macro-economic slowdown and inflation, the main coping strategy of household is to have several sources of job known as occupational multiplicity [29], [30], [31], [32].

Findings suggest that each household also has the primary and secondary occupations. The primary job of farmers is agriculture, fishermen, handyman, motor cycle driver or religion teacher. The same pattern occurs to the head of household having primary job in home industry, trade, services as well as government or private employee. Farmers cultivate crops but at the same period they also catch fish in the sea, work as a handyman, driver of motor cycle, pedicab driver and elementary school or religious teacher. Therefore, multiple occupation is coping strategies to avoid risks and uncertainty of household income.

Data show that around $75 \%$ of respondents have nonproductive assets whilst $25 \%$ have small scale productive assets such livestock and saving money/gold with value between \$US105 and US\$1053. Households with productive assets develop multiple occupations as a consolidation and accumulation coping strategies. As a consolidation strategy, households have to have saving and several jobs just in case they need additional money for unpredictable situations such as children education, illness costs, social cultural-religion activities or inflation. As an accumulation strategy, households multiply and accumulate productive assets. There are only 8 out of 200 households (4\%) who save money in the Bank but it was only $2 \%$ of them have accumulation strategy, i.e. farmers and traders/micro business, who save money (less than US \$1,053), and gold (less than 1.3 grams) and also invest in motorcycle as local transportation. Profit from farm or trade is used to save in order to accumulate financial capital asset. This indicates that it is difficult to change the mind set of the poor into entrepeneurs' maind set.

Different from the first households, the second households without productive assets develop multiple occupations as a survival strategy. In this case, income from one occupation is not enough to fulfill daily basic needs of the family. Therefore, they must have multiple occupations to survive and to fulfill daily basic need of the family members. Urban poor will borrow from neighbors when faced unpredictable situation such as business or harvest failure, inflation, illness, housing renovation, cultural and education costs. A woman as head of household (widow) must be working hard to make and sell bread, and doing laundry in different places in order to get cash money for daily food of family members. In the same way, a poor husband must work on small scale farm and then work as tukang becak (pedicab driver) whereas at the same time the wife work to sell vegetables and fish in order to get enough cash money to fulfill basic needs of the family member.

In can be seen that existing livelihood coping strategies is developed by urban poor households without external intervention from government and private institutions.
Results show that urban poor households actually expect five priorities intervention and facilitation from external institutions to strengthening the existing livelihood coping strategies and to reduce urban poverty. These five priorities are as follows: (1) $72 \%$ households need financial capital assistance for developing productive business; (2) $16 \%$ households still need direct cash money; (3) $8 \%$ respondents need assistance for housing costs because around $56 \%$ of migrants household live in rental houses; and (4) $4 \%$ households only need to continue rice for the poor program whislt the rest of $0.5 \%$ households need free medicine costs assistance. Thus the high priority of urban poverty reduction is financial assistance to empower the productive economy whereas the last priority is rice for the poor and health insurance.

\section{Conclusions}

The profiles of urban poverty in Ambon city can be depicted as household' members with low formal education and skill, high number of household members, and lack of access to credit. Poor households are also self-employed and work in multiple informal occupations and uncertain income from services, micro-enterprises, public employee and private worker. Most of them have low wages and low household income uncertainty. Around $67 \%$ of total expenditure is used for food and up to $75 \%$ of households have no productive capital assets. Moreover, most of urban poor households are not only poor, very poor and destitute, but also deprived in sanitation, productive economic assets, housing and drinking water.

Urban poverty can be caused by both internal and external factors. The first factors are based on individual or household weaknesses and social cultural structure, whereas the second factors are based on external policy intervention and geographical poverty traps. Cultural factors are the high number of family member and women headed households, low trust, lazy behavior, narrow mindset for economic and business development, limited social and business network. High number of children has become burden for urban poor family and created the next poor family member generation.

Structural and geographical factors of urban poverty are caused by isolation, lack of accessibility to market, including government policy in terms of misuse of rice for the poor subsidy program. Rice for the poor subsidy policy is useful to reduce poverty burden, but this policy fails to address the urban poor target groups in the city because $52.4 \%$ of 'not poor households' received rice for the poor program and $71.8 \%$ of destitute people fail to receive rice subsidy.

Generally, isolation and lack of connectivity within and between islands is geographical poverty trap in Maluku. Generally, closer distance of villagers to the urban area will have a better access to market and create better income and prosperity. In fact, urban poverty rate is higher in the city center than that of in the periphery of city areas. In this case urban poor households are segregated and isolated from competitive employment opportunities and modern market 
economy so that they probably fail to improve the living standard of the family member who live in urban and rural areas. Finally, sanitation infrastructure status has positively influenced urban poverty reduction, however, most of urban poor households are deprived in sanitation. It can be argued that poor households priority is basic needs rather than improvement of environmental degradation and sanitation. In fact, poor households are vulnerable to get illness, fever, malaria and diarrhea because they have poor access to green environment as well as waste and garbage management.

Moreover, many urban poor households practice livelihood strategy which is called occupational multiplicity to reduce risks and uncertainty. The poor, destitute and very poor households used survival strategy to fulfill basic needs of the family members whilst the non-poor households use occupational strategies as a consolidation or accumulation strategy to anticipate accidental shock such as inflation, illness of family members, social cultural and religious activities, and unpredictable natural disaster. Most households have no access to bank as there is $19 \%$ respondents having access to credit from bank and cooperatives but only $4 \%$ of households who save small amount of money in the Bank.

Therefore, there are many complex reasons for urban poverty but there is no one solution that fit to all because to alleviate urban poverty needs holistic, systemic and comprehensive approach [33]. However, the main target of urban poverty are those households who are living in the center and periphery of the city. Thus, the priority program to reduce urban poverty can be seen from the perspective of the poor, that is, financial assistance and technical skill to improve income and empower the economy of economically active urban poor to increase and sustain productive employment [34]. Then, social protection program such as rice price subsidy and direct cash money are still pivotal to continue for the very poor and destitute households but it needs to address the right target. The other policy is to invest and create non-farm economic activity and secondary town between village and the city center to absorb rural labor and reduce urbanization.

Different from the previous policy, the other government policy to accelerate poverty reduction in rural and urban areas in Ambon islands is likely to develop middle economic activities, called rural non-farm economy and secondary towns to link and bridge the economic activities between rural-agriculture and megacities including market oriented policy and microenterprise, infrastructure and tenure security $[35,36,37]$. In this case, rural people will not move directly to megacities but they move first into rural non-farm economic base and secondary towns to get money, and then they will send the money back to rural people to reduce rural poverty. Finally, to avoid segregation of urban poor from market labor and employment opportunities, local government needs to revisit land use plan, provide better basic infrastructures, social protection and inclusion, including sanitation, housing and transportation systems as well as population density and distribution arrangements with the other districts. Otherwise, urban poverty in the small island may continue to create more slum areas, social economic and environmental problems.

\section{References}

[1] CBS, 2014. Maluku Province in Figures. Cooperation between Central Bureau Statistic and Regional Planning and Development Board, Ambon.

[2] PSF, 2013. Indonesia: Kemiskinan Perkotaan dan Ulasan Program.Kerjasama Kementerian Koordinator Bidang Kesejahteraan Rakyat, Pekerjaan Umum dan PNPM Mandiri. Laporan Penelitian. PNPM Support Facility. Jakarta. Pp.44. [Indonesia: Urban poverty and Program analysis. Cooperation between Ministry of Social Welfare, General Work Ministry and National Community Empowerment]. Research Report-PNPM Support Facility.

[3] Dartanto, T., and S.Otsubo, 2013. Intra-generation poverty dynamics in Indonesia: Lessons on household s mobility into (out of) poverty during 1993-2007. Paper presented in The $23^{\text {rd }}$ Pacific Conference of the Regional Science Association International (RSAI) and The $4^{\text {th }}$ Indonesian Regional Science Association (IRSA) Institute, 2-4 July 2013, Bandung. Indonesia.

[4] Guan, J and McElroy, J. L., 2012. The Determinants of Migration in Small Islands. Shima: The International Journal of Research into Island Cultures, Volume 7 Number 12012

[5] Nguyen, L. D, Raabe, K, Grote, U. 2012. Rural-Urban Migration, Household Vulnerability, and Welfare in Vietnam. World Development Vol. 71, pp. 79-93, 2015

[6] World Bank, 2012. World Bank, 2012, Indonesia, The Rise of Metropolitan Regions: Towards Inclusive and Sustainable Regional Development, Jakarta, dan World Bank, 2012, Protecting Poor and Vulnerable Households in Indonesia.

[7] Harris, J. 1989. "Urban poverty and urban poverty alleviation."Urban poverty and urban poverty alleviation.

[8] Saleh, D. Z., 2013. Potret Dhuafa Perekonomian Indonesia Dalam Statistik, Ide danTerapan. Expose. Bandung. [The profile of Dhuafa Indonesian Economic in Statistic, Ideas and Implementation]

[9] Harris-White, B. 2004."Destitution and poverty of its politicswith special reference to South Asia." World Development 33:881-891.

[10] Sumner, A., and Edward, P., 2013.From Low Income, High Poverty to High-Income, No Poverty? An Optimistic View of the Long-Run Evolution of Poverty in Indonesia By International Poverty Line, 1984-2030, pp.32 The SMERU Research Institute.Jakarta.

[11] Abro, J. A. Alemu, B. A and Hanjra, M. A. 2014.Policies for Agricultural Productivity Growth and Poverty Reduction in Rural Ethiopia, World Development Vol. 59, pp. 461-474, 2014

[12] Turner, Jack, 2011. SejarahRempah: Dari Erotisme Sampai Imperialisme.[From Erotism to imperialism] Komunitas Bambu. Depok.

[13] Grydehoj, A and Hayward, P. 2014.Social and economic effects of spatial distribution in island communities: Comparing the Isles of Scilly and Isle of Wight, UK, Journal of Marine and Island Culture (2014) 3, 9-19 
[14] Girsang, W. 2011. Kemiskinan Multidimensional di PulauPulau Kecil, Ambon, Badan Penerbit Universitas Pattimura. [Multidimensional poverty in small islands, Faculty of Agriculture Press, Pattimura University]. Ambon.

[15] Alcock, P. 1997. Understanding PovertyLondon, Macmillan Press.

[16] Ravallion, Martin (2010) "A Reply to Reddy and Pogge" in SudhirAnand, Paul Segal and Joseph E. Stiglitz (Editors), Debates on the Measurement of Global Poverty,Oxford: Oxford University Press

[17] Sajogyo 1978. Lapisan yang paling lemah di pedesaan Jawa. Prisma, 4, 50-62.

[18] Tjondronegoro, S., Soejono, I., and Hardjono, J. 1996. Poverty in Indonesia In: QUILIBRIA, M. G. (ed.) Rural Poverty in Developing Asia. Part 2: Indonesia, Republic of Korea, Philippines and Thailand. Manila: Asian Development Bank.

[19] Damanik, I. P. N, Girsang, W., Tahitoe, M. E, 2009.Model pembangunan dan pengembangan pengentasan kemiskinan perkotaan di kota Ambon [Development model for urban poverty alleviation in Ambon city]. Laporan Penelitian Hibah Bersaing [Research competitive Grant, Research and Community Service Research Agency, Ministry of Higher Education, Indonesia]. DP2M Dikti. Jakarta.

[20] Alkire, S. and Foster, J., 2012.Counting and Multidimensional Poverty Measurement, Oxford Poverty \& Human Development Initiative, Department of International Development, Queen Elizabeth House, University of Oxford.www.ophi.org.uk.

[21] Alkire, S. and Santos, M. E, 2010.Acute Multidimensional Poverty: A New Index for Developing Countries. Human Development Research Paper 2010/2011, pp.100. United Nations Development Program.Oxford Poverty \& Human Development Initiative, Department of International Development, Queen Elizabeth House, University of Oxford.www.ophi.org.uk.

[22] Papilaya, E. Ch. and Ginting, B., 2006. Akar Dan StrategiPengentasanKemiskinan Di Kota Ambon, Maluku Dan KabupatenBoalemo, Gorontalo (The Roots And The Strategy For Poverty Alleviation In The City Of Ambon, Mollucas And In The District Of Boalemo, Gorontalo), JurnalPenyuluhan (Extension Journal), Desember 2006, Vol. 2, No. 4, InstitutPertanian Bogor (Bogor Agricultural University), pp. 23-32, ISSN: $1858-2664$

[23] Cortes, P. 2015. The Feminization of International Migration and its Effects on the Children Left Behind: Evidence from the Philippines, World Development Vol. 65, pp. 62-78, 2015

[24] Alaydrus, D and Girsang, W and Anneke. 2014. Profil kemiskinan anak di kota Ambon [Child poverty profiles in Ambon city]. Unpublished Undergraduate Thesis. Faculty of Agriculture University of Pattimura Ambon. Pp.50

[25] Hetharia, M. and Adam, E., 2012. Analisis Dampak Migrasi terhadap Keadaan Sosial Ekonomi di Maluku. Kerja sama Puaslitbang Kependudukan (PUSDU) BKKBN Pusat dengan Pusat Studi Kependudukan dan Kesejahteraan Masyarakat Universitas Pattimura. Research Report. Pp.44.[Migration impact analysis on social economic in Maluku province]. Cooperation between Population Development Research Centre-National Family Planning Board and Population Studies of University of Pattimura, Ambon].
[26] Bird, K., Higgins, K., and Harris, D., 2010.Spatial poverty traps.ODI Working paper 321 and CPRC Working paper 161. Overseas Development Institute and Chronic Poverty research Center. 111 Westminster Bridge Road, London SE17JD.www.odi.org.uk

[27] Curley, A. M, 2005. Theories Of Urban Poverty and Implications For Public Housing Policy, Journal of Sociology and Social Welfare, June, 2005, Volume XXXII, Number 2

[28] Sambodo, M. T, Lestari, E. and Ermawati, T., 2014. Rice for the Poor: Evaluating Expenditure and Infrastructure Criteria, in Fahmi, M., Yusuf, A. A, Purnagunawan, R. M, Resosudarmo, B.P, Priyarsono, D. S., Government and Communities: Sharing Indonesia's Common Goals. IRSA Book Series on Regional Development, Indonesian Regional Science Association-Universitas Padjadjaran.UNPAD Press. Bandung, p.173-192.

[29] White, B., 1990.Agroindustri, Industrialisasi Pedesaan dan Transformasi Pedesaan, dalam Sajogyo dan Tambunan, M (eds), Industrialisasi Pedesaan.PSP-LP Institut Pertanian Bogor dan ISEI Jakarta.Bogor. [Agro-industry, Rural Industrialization and Transformation, in Sajogyo and Tambunan (eds), Rural Industrialization].

[30] Girsang, W., 1996. Penguasaan lahan dan strategi hidup rumah tangga: Kasus di desa transmigrasi Waihatu, Seram Barat, provinsi Maluku. Unpublished thesis.Program Pascasarjana Institut Pertanian Bogor.Bogor. [Land occupation and livelihood strategies: A case in Waihatu Transmigration Village, Western Seram, Maluku province.Unpublished Thesis, Bogor Agricultural Institute Postgraduate]

[31] Girsang, W., 1997. Kesenjangan di desa transmigrasi [Inequality in Transmigration Village].Kompas, pp.4.Jakarta

[32] Van Oostenbrugge, J. A. E., W.L.T Van Densen, and M.A.M. Machiels 2004. How the uncertain outcomes assosiated with aquatic and land resource use affect livelihood strategies in coastal communities in the Central Moluccas, Indonesia. Agricultural Systems, 82, 57-91.

[33] Teitz, M.B and Chapple, K. 1998. The Causes of Inner-City Poverty: Eight Hypotheses in Search of Reality, Cityscape: A Journal of Policy Development and Research, Volume 3, Number 3,1998, pp. 33-70. U. S. Department of Housing and Urban Development, Office of Policy Development and Research.

[34] Samanta, D. 2015. Urban Poverty in Developing AsiaDichotomy Between the Income and Non-income Dimensions: Are We not Grossly Underestimating Its Incidence?inHeshmati, A, Maasoumi, E., Guanghua Wan (Editors), Poverty Reduction Policies and Practices in Developing Asia, Co-publication of the Asian Development Bank and Springer International Publishing AG, pp. 79. Pp.309

[35] Christiaensen, L and Todo, Y. 2014. Poverty Reduction During the Rural-Urban Transformation - The Role of the Missing Middle, World Development Vol. 63, pp. 43-58, 2014

[36] Imai, S. K, Gaiha, R and Thapa, G.2015.Does non-farm sector employmentreduce rural poverty and vulnerability? Evidence from Vietnam and India, Journal of Asian Economics 36 (2015) 47-61

[37] Gulyani, S and Talukdar, D. 2010. Inside Informality: The Links Between Poverty, Microenterprises, and Living Conditions in Nairobi's Slums, World Development Vol. 38, No. 12, pp. 1710-1726, 2010. 